\title{
A Sociocultural Study on EMOTIONALITY AND Cognttion as Features of Teacher KNowledge and Practice
}

\author{
Un Estudio Sociocultural de las Emociones y la Cognición como \\ Elementos de los Saberes y las Prácticas Docentes
}

\author{
Mabel Encinas Sanchez \\ PhD Student, Institute of Education \\ University of London \\ liliamabel@hotmail.com
}

Received: May 7, 2008. Accepted: August 13, 2008

\begin{abstract}
Although acknowledged, emotions have been consistently bracketed out of research on teacher training (Goodson, 1992; Day, 1993; Cochran-Smith and Lytle, 1999), and sociocultural approaches (Lave and Wenger, 1991; Lave and Chaiklin, 1993; Salomon, 1993). Emotions have been considered as independent of social practices, reducing them to a subjective perspective (Hargreaves, 2000, 2002a, 2002b). However, emotions have recently been studied in sociology (Williams and Bendelow, 1998), particularly through the concept of emotional labour (Hochschild, 1983). These perspectives emphasize the social construction of emotionality, but they leave the complexities of individual participation in the context aside. By contrast, through the construction of an immanent, non-Cartesian, psychology derived from Vygotsky's (1999) work, space is created for an account of emotionality in individual teacher practices and its role in teacher knowledge. This ethnographic case study involved an intervention in a Mexican urban secondary school (junior high school). The work was developed with four experienced teachers and it was during the analysis of the video and audio recordings and notes, that emotions within social relationships in the classroom were unveiled as an important part of teacher practice and knowledge. Findings so far confirm the social character of emotion by describing how it develops in the social context of the classroom, and suggest that emotions are products and resources in social interaction in the classroom. Finally, these findings open important questions to the understanding of teachers' practice and knowledge, to cultural psychology and to neurosciences.
\end{abstract}

Keywords: Socio-cultural approach, emotion, affect, teacher practice, teacher knowledge, teaching context.

Resumen: A pesar de ser reconocidas, las emociones han sido consistentemente puestas entre paréntesis en la investigación sobre formación de maestros (Goodson, 
1992; Day, 1993; Cochran-Smith y Lytle, 1999) y en los enfoques socioculturales (Lave y Wenger, 1991; Lave y Chaiklin, 1993; Salomon, 1993). Las emociones han sido consideradas como independientes de las prácticas sociales, quedando reducidas a una perspectiva subjetiva (Hargreaves, 2000, 2002a, 2002b). Sin embargo, han sido estudiadas en sociología (Williams y Bendelow, 1998), particularmente a través del concepto de trabajo emocional (Hochschild, 1983). Estos enfoques enfatizan la construction social de la emocionalidad, pero dejan de lado las complejidades de la participación del individuo en el contexto. Por el contrario, a través de la construcción de una psicología inmanente, no-cartesiana, derivada del los trabajos de Vygotsky (1999), se crea un espacio para dar cuenta de la emocionalidad en las prácticas individuales del maestro y su rol en los saberes.del mismo. Este estudio de caso etnográfico involucró la intervención en una escuela secundaria urbana de México (grados 70 a 9). La investigación se llevó a cabo con cuatro maestros con experiencia, y fue durante el análisis de los videos, audios y notas de campo que las emociones al interior de las relaciones sociales en el salón de clases se revelaron como una parte importante de las prácticas y saberes docentes. Los hallazgos, hasta el momento, confirman el carácter social de las emociones al describir cómo se desamollan en el contexto social del aula, y sugieren que las emociones son productos y recursos en la interacción social en el salón de clases. Finalmente, estos resultados plantean importantes interrogantes para la comprensión de las prácticas y los saberes docentes, para la psicología cultural y para las neurociencias.

Palabras clave: enfoque sociocultural, emoción, afectividad, práctica docente, saber docente, contexto de enseñanza.

\section{INTRODUTION}

The present article is divided into four sections. The first one is the literature review, where it is depicted how a new understanding of emotions as social opens possibilities in research about teachers' practice. The second section describes the research, which comprises the research context, questions to be answered, and an overview of the process of methodological decisions. In the third section, an extract of the analysis of the data is presented. Finally, some implications of the results so far are discussed.

\section{COGNITION AND EMOTION IN CONTEXT}

The efforts for understanding emotions have followed parallel steps to those followed for the understanding of cognition, by reframing their explanation from the concentration in individuality to a broader comprehension of individuals in the social context. In this process, Vygotsky (1978, 1987, 1997, 1999) hints at the possibility of studying emotions in social practices. 
Socio-cultural approaches have challenged perspectives on cognition and knowledge that consider the mind as consisting of mental processes that take place inside the individual and that regard the context as an environmental variable that influences cognition and knowledge. To a certain extent, for some of the perspectives that put the context as surrounding the individual, biology has a pre-eminence in the developmental processes over the social context (for example, Piaget, 1968). In contrast, during the last decades, research from a socio-cultural perspective, developed from Vygotsky's (1978, 1999) work, as in the case of cultural psychology (Cole, 1996), has revealed that participation in social contexts is fundamental for the development of cognition and knowledge (Lave and Wenger 1991; Lave and Chaiklin, 1993).

In fact, cognition has been described as transcending the individual mind, not in an idealistic way, but regarding it as situated (Scribner and Cole, 1981, Lave and Wenger, 1991). The mind is in fact embedded in artefacts and in the practices that make use of those artefacts (Engeström, 1987; Salomon, 1993, 1994; Nardi, 1996; Nardi and O’Day, 1999).

Artefacts do not have only a material existence, as they also involve the ideas of those that produced them in the past (Cole and Derry, 2005). What is more, the use of artefacts triggers, in principle, cognition and knowledge production, in a dynamic dialogic as much in ontogeny as in phylogeny of human beings (Cole and Derry, op. cit.). In a similar way, studies about teacher knowledge have recognised that such knowledge is re-constructed in the teaching context, through teaching practices and within them, via social relationships (Mercado, 2002).

However, in all those studies, emotions and affects are ignored, even if they are mentioned. Possibly this occurs because emotions are considered a part of the biological realm; perhaps as a residue of positivistic preoccupations in relationship to the irrelevance of emotionality in scientific disciplines (Williams and Bendelow, 1998a), knowledge should be dispassionate (Jaggar and Bordo, 1989). Williams and Bendelow (1998b) assert that it seems that emotions are "lurking in the shadows or banished to the margins of sociological thought and practice" (op. cit.: xv), and this can apply to socio-cultural research as well.

\section{EMOTIONS AND SOCIAL LIFE}

In the 1980s, emotions started being studied in sociology, mainly thanks to the fruitful concept of emotional labour as coined by Hochschild (1983). She pointed out that workers' emotional management aimed to produce a 
particular emotional state in others. There are certain "jobs that call for emotional labour" (op. cit.: 147), she established, and analysed the case of flight attendants, and how they manage their behaviour according to certain feeling rules. In the same fashion, teachers also display or refrain from displaying certain emotions in order to produce an effect in their students (Labaree, 2000) and other people inside the school (Hargreaves, 2002). For, example, a teacher can show enthusiasm towards a topic she is teaching, independently of her particular appreciation for it; another teacher could refrain from expressing his anger for the students' behaviour, as teachers are not expected to become emotionally involved. Hochschild (1983) sustains then that individuals sell their "emotional self" for the benefit of institutions, and thus, she underlines the social character of this process that cannot be explained in biological terms only.

Three basic elements from Hochschild's $(1983,2005)$ theory of emotional labour are underlined: (1) the importance of the context, in particular the feeling rules, for understanding how individuals handle their emotions (Ashforth and Humphrey, 1993; Morris and Feldman, 1996; (2) the fact that individuals get actively involved in demonstrating certain emotions, and (3) that the purpose of emotional labour is to produce a response in others.

Undoubtedly, her approach finds a turning point in the understanding of emotions: they are played in the social ground. However, the weakest point of this perspective is the fact that emotions seem to be reduced to the individual's engagement in an active emotional display, leaving aside the complex process between what is unconscious, not conscious, in the individual's emotions and conscious emotional management. Hochschild (1998) presents the example of a bride: she realises that she must be happy on 'the happiest day' of her life, and at a certain point she genuinely starts feeling happy. Certainly, the handling of the emotions is there, being played in the social ground. However, the author disregards all the other emotions that factored into the bride' story.

Independently of the limitations of Hochschild's theory, this shift towards a sociological account of emotions, which can also be traced in anthropology (see for a recount: Lutz and White, 1986), started to suggest that there is a transformation in the understanding of emotions. We sustain that this process is similar to the process through which cognition has passed, in the last century. On the one hand, cognition has moved on from being considered individual, internal, biologically settled and psychologically analysable, to being recognised as social, interactional, practice-based and culturally analysable. Cognition is much more than a mental process; it is embodied in 
the body itself, as well as in the activities and in the settings where those activities take place (Lave, 1998; Cole, 1996). Hence, cognitions have passed from being considered invariable across cultures and part of the unchangeable human essence, to be variable in relationship to the context and as culturally constructed.

In parallel with this transformation in the understanding of cognition, there has also been a change in the concept of learning, having been extended from acquisition and internal transformation, to also include participation and external transformation (Engeström, 1994; Engeström and Middleton, 1998). Rainbird, Fuller and Munro (2004), for example, consider that two metaphors of learning pervade the field of workplace learning: learning as acquisition and learning as participation. As a result of this shift in the understanding of cognition, the mind cannot be reduced to existing only inside the head. In this way, as Shweder (1990) points out, the mind is "contentdriven, domain-specific, and constructively stimulus-bound... [and] cannot be extricated from the historically variable and culturally diverse intentional worlds in which it plays a co-constitutive part" (op: cit.: 13). Interestingly, this context-bound quality of the mind does not imply a determination of conscious content, but a complex dialogic process of construction.

On the other hand, as Csordas (1990, 1994), declares: emotions must be seen as culturally situated practices. In this way, debate about emotions has started a journey on a similar path to those about cognition: from the biological reduction, to the comprehension of how human biology is only enacted in social contexts, i.e. to the comprehension of how nature becomes a part of a nurturing context in the emotional and affective life. Or expressed the other way round, on how nurturing transforms nature, in a dialogical way. Interestingly, far from emphasizing the dichotomies between the two poles, the genetic and the social, the process starts finding how these links are part of the complex historical processes of human beings, ratifying what cultural psychology started to discover (Cole, 1996). However a discussion on this topic will not be a focus of this paper.

In this analogous process between cognition and emotion, the line between them starts being blurred. This change is the result, not only in terms of the research undertaken in diverse fields from neurosciences (Damasio, 1994, 1999) to sociology and anthropology, but also in philosophical terms. In this sense, Vygotsky's work is invaluable in supporting the definition of an immanent psychology, i.e. a non-Cartesian psychology. 


\section{VYGOTSKIAN PERSPECTIVE ON EMOTION}

Vygotsky's (1987) position is, before anything else, philosophical. He is looking to build an immanent psychology, i.e. a non-idealistic/dualistic psychology. He points out to a crisis in psychology that he explains as a methodological problem. However, in his view, the main problem comes from the Cartesianism implicit in diverse perspectives, including among others the work of Freud, Piaget and the most spread out theory of emotions at the time: James and Lange theory (James, 1884).

For Vygotsky $(1987,1993,1999)$, it is necessary to start by taking as a departure point the unity of affect and intellect. This means that needs and adaptation must be considered in their unity, in opposition to an idealistic psychology. While in an idealistic perspective human needs are considered subjective and therefore in opposition to the possibilities of adaptation to the material and social world, in Vygotsky's view, in his own words:

"Adaptation to objective reality simply for the sake of adaptation, adaptation independent of the needs of the organism or personality, simply does not occur. All adaptation is directed by needs. This is a rather banal notion, even a truism, butit has somehow been overlooked in the development of the theoretical perspectives that we have considered here" (Vygotsky, 1987: 76-77).

Considering this unity, Vygotsky criticizes both Freudian and Piagetian perspectives. In the case of Freud (1971), the pleasure-principle seems to be in opposition to the reality-principle. The former, "the tendency to satisfy needs" and, the later "the tendency to adapt to reality" do not represent polar opposites (Vygotsky, 1993: 239). On the contrary, both principles are integrated with each other, as the satisfaction of needs is the flip side of the adaptation process. Pleasure and reality do not contradict or exclude each other, to the extent that, according to Vygotsky (op. cit.), they almost coincide in infancy. In this way, affect and intellect are closely and inseparably connected throughout life. Nevertheless, he recognises in Freud the pioneer in demonstrating precisely that emotions change in individual development.

For Piaget (1973), the biological and social realms are in opposition with each other, in the child's journey from heteronomy to autonomy. According to Vygotsky, "The soul of the child dwells in two worlds" (1987: 84), suggesting that the child is separated from the social whole, without social relationships, and independent of social practices. In that way, society is outside the child's world, as a foreign domain, that she has to apprehend not through contact with reality, but by accommodating her ideas to others' ideas. The process 
then seems to go, in both cases, from the most corporeal to the highest levels of ideas. Although recognising Piaget's richness, especially in methodological terms, again Vygotsky's critique underlines the point about the breakage of unity.

The third, and maybe most important object for Vygotsky's (1987, 1999) critique in relation to emotions, is the James and Lange theory. These authors consider that emotions consist of the perceptions of our own organic reactions towards environmental stimuli, synthesized in James' famous phrase: "I am sad, because I cry". This is an apparent materialistic perspective that was associated in its origins to Spinoza (1959), however, Vygotsky calls attention to the implicit dualism in this theory and its Cartesian basis. Interestingly, he says that a dualist theory "cannot be called materialistic".

Certainly, he recognises that James and Lange offer, for the first time, a natural-scientific, biological basis for explaining emotions, although simultaneously they "provided the foundation for a variety of metaphysical theories of the emotions" (Vygotsky, 1987: 328). On the other hand, this perspective does not allow room for the understanding of emotions historically, that is to say, genetically.

One question that intrigued this author was how emotions developed in human history, and he hints at the need for a study of emotions in the context of practices. This can be used as a departure point: the need to understand emotions in practice, as complex constructions of biology that can only be played out within a social context. Vygotsky (1998) states that while individual psychology negates the essential connection between the organic substrata and the overall psychological development of personality and character, a socio-cultural perspective could also be built into the social terrain through studying participation in social contexts. The consequence that he finds from this is that "the entire psychological life of an individual consists of a succession of combative objectives, directed at the resolution of a single task: to secure a definite position with respect to the immanent logic of human society, or to the demands of the social environment." (op. cit., p.: 55). In this sense, psychological research would need to understand not only the past, but also the future of personality, which represents --his own words- "the ultimate direction of our behaviour... the daily social demands... the future oriented tendencies" (op. cit., p. 55).

Actually, however, it is also necessary to understand how emotions are played out in the context of practices (Roth, 2007), where effectively the future is present, in terms of the object, not only as a thing but as an ideal, 
and also in terms of the motive (Engeström, 1987; 1994), but the demands of the situation are present as well (Suchman, 1987). It is in this very context that emotions have their place. From a socio-cultural perspective, it is possible to start tracing the way in which emotions are played out in the context of practices. In brief, the orientation to the future does not deny the fact that emotions are played out in the present.

Finally, the interplay between emotions and thinking seems important for Vygotsky, as the thinking in the culture in which individuals participate, imposes "a system of concepts" that also involves feelings. Feelings that come into consciousness in fact modify the feelings when they enter into a connection with our thinking. Furthermore, following Spinoza (1959) in the process of ontogenetic development, human emotions are connected with both the individual's self-consciousness and his knowledge of reality (Vygotsky, 1998). These factors provide the opportunity for the historical development of complex emotions.

These are the threads that this research will tie together. The study of emotions as they are played out in the social space, concretely, by participant observing what takes place in the classroom, could imply understanding emotions in the wild and even distributed emotions. This suggests an appreciation of the future, but also the understanding of emotions as grounded in the present situation. A second stage in this process, which will not be fully developed in this paper, is to enter into the complexities of the ways in which cognition and emotion work together in teaching practices and in teacher knowledge.

The study presents a descriptive example of emotions in classroom contexts and also discuses how this suggests that emotions are not only products, but also resources for social interaction within the classroom.

\section{THE RESEARCH}

This section will briefly present the research context, the research problem and objectives and an overview of the methodological decisions.

\section{Research context}

The research took place in an urban secondary school (junior high school) in Mexico City during the afternoon shift, a school participating in the $\mathrm{Sec}^{21}$ Project. This is a project in which schools have a local area network installed, with one computer in each subject classroom and two media classrooms. The 
Sec $^{21}$ Project involved digital video and audio, general use software, programmable calculators for maths, and laboratory equipment for science. The subjects were Spanish, mathematics, history, geography, biology, chemistry, physics and civic education. The Project also included teacher training and visits from the members of a central team. This training was mainly technical, although it was not planned in that way.

All the schools in the project had relatively 'good results', according to official figures, however general population with lower incomes send their children to the afternoon shift, as they count with less resources to push for a place in the morning one. The afternoon shift also has an impact on a student's life, as they spend many hours a day alone at home, while their parents are at work.

At the beginning of the research, Spanish teachers in all the schools in the Project received an invitation for a workshop in the use of Information and Communication Technology (ICT) for mother tongue teaching with a communicative perspective. The teachers that attended were informed that a research was going to be undertaken in one of the schools that were interested. From the schools that expressed interest one was chosen from the lower half of the schools that participated in $\mathrm{Sec}^{21}$. Additionally, it is important to point out the fact that afternoon shifts tend to shrink, and even disappear with the changes in the growing rate of the population and, in the school where the research finally took place, the groups were actually smaller than the average in Mexican secondary schools. In addition, secondary schools are becoming more difficult to 'handle', according to teachers' perceptions, due to behavioural problems.

The research counted with four experienced teachers, three female and one male, for a period of approximately eight months. Each had more than ten years of experience and some knowledge of computers. However, at the start of the process, they had only used the media classrooms a few times and had watched only a few videos with the students. Organisationally, the school had not assigned the use of the media classrooms; however, an important change was developing: in Mexican secondary schools, each group usually remained in his own classroom, and the teachers came to them. Part of $\operatorname{Sec}^{21}$ 's reorganisation proposal was to work with assigned subject classrooms, and the groups had to move from one classroom to the other between classes. Also, there were only two equipped Spanish classrooms, and on many occasions the four teachers were all in, so one or two of them had to work in classrooms not assigned to any subject, and that did not therefore have any equipment installed. 


\section{THE PROBLEM AND THE METHODOLOGICAL DESIGN}

The problem stated as a research question is: In what ways are emotion and cognition integrated in teachers' practice and knowledge when teachers face an innovation? The answer implies two things. On one hand, this research aims to describe emotions in the social contexts of the classrooms: the ways in which they are played out as part of the teacher's participation in the practice of teaching. On the other hand, it aims to describe the ways in which emotions are inseparable from teachers' practice, and also from teachers' knowledge.

This study is drawn as an observation informed by ethnography. However, it started as an intervention for organising the school in supporting the use of ICT in different subjects, and leading a workshop with the teachers with the aim of planning the work they could do with the ICT in their teaching. The intervention was informed by the Activity Theory. After that initial period, the intervention took place more in terms of accompanying the process, through participant observation. It is, as mentioned above, a case study in a secondary school, with four teachers. The research mainly took place in the media classroom and the Spanish subject classroom, and semi-structured and nonstructured interviews were carried out. The observations were video recorded, and many of the interviews were audio-recorded. Additionally, notes were taken throughout the process.

The participant observation did not follow the characteristic traditional engagement of ethnography, as it lasted only a few months (from June 2003 to January 2004). That is to say, from the end of the 2002-2003 school year to the middle of the 2003-2004 year. It is important to highlight that, at the beginning of the process, the research strategy had never considered studying emotions. They appeared during the period of data analysis, as will be explained in the following section, when no sense could be made of data with the theoretical tools at hand. At this stage of the fieldwork then, the research aim was looking at teachers' practices during the starting time of innovation rather than looking for (I take this expressions from Bakker et al., 2006) emotions appearing in a way in which they could be associated to teacher knowledge.

At the moment, this research is still in the analytical stage, trying to make sense of how the whole argument could be built by establishing a real dialogue between theory and data. Additionally, it turned out that the transcriptions of observations made during the process were not enough to give an account of the way in which social relations took place in the classroom. The video 
footage is currently being analysed using Atlas TI in an attempt to capture the way in which emotions are played out in the social context, starting with the initial stage of codification. This involves reviewing 40 videos, about 10 of each teacher, and finding those situations in which the presence of emotions is evident. That the segments where emotions are evident are selected for further analysis does not imply that there are dispassionate moments; on the contrary, it implies that there are moments in which emotions in interactions can be more easily identified.

Additionally, triangulation is an important concern for the researcher (Hammersley and Atkinson, 1995) as -independently of having been an insider, a Mexican, and a former secondary school teacher- there is a need to relay the interactions to support which emotions are played out and in which way. There is the possibility of going back to the teachers with some interpretations about the way in which emotions are played out in the classroom, and how they form part of the teachers' knowledge.

\section{AN EXTRACT OF THE ANALYSIS}

This section presents an example of the data and a fragment of the analysis, which is currently underway. The results so far start giving account of certain processes in the classroom where teachers' emotions and cognition work together, however, this article will focus on the ways in which emotions develop in the social context of the classroom and seem to be both products and resources of social interaction in the classroom.

At the beginning of the analytical process, Table 1 was used to compare certain aspects found in the transcriptions and the notes. Certain relationships started to emerge among the social relationships that took place in the classroom and the way in which ICT was used for teaching. It is important to mention that both teachers, Sofia and Ricardo, in their first individual interview, expressed their intention of teaching Spanish from a communicative perspective, and both of them had used ICT with their students in few occasions. 


\section{Table 1 - Comparison between two teachers' uses of technology}

\begin{tabular}{l|l}
\hline \multicolumn{1}{c|}{ Sofía } & \multicolumn{1}{c}{ Ricardo } \\
\hline $\begin{array}{l}\text { Smooth relationship and intensive } \\
\text { negotiation with the students }\end{array}$ & $\begin{array}{l}\text { Extremes in the relationship, alternating } \\
\text { between fighting with students, and } \\
\text { allowing things that other teachers do not. } \\
\text { Low influence on students' actions. }\end{array}$ \\
$\begin{array}{l}\text { High influence on students' actions } \\
\text { children" }\end{array}$ & $\begin{array}{l}\text { Considers students to be "badly behaved" } \\
\text { because they are "young". }\end{array}$ \\
$\begin{array}{l}\text { Variety of writing and research activities } \\
\text { Software: Office tools, encyclopaedias, }\end{array}$ & $\begin{array}{l}\text { Grammar drill and practice software and } \\
\text { informative papers. }\end{array}$ \\
$\begin{array}{l}\text { ICT fornet } \\
\text { interchange. }\end{array}$ & ICT as tool for 'control'. \\
\hline
\end{tabular}

While Sofía had a smooth relationship with the students, in which they seemed to collaborate, Ricardo had a lot of problems with them and seemed to be travelling between two poles: sometimes he allowed them to break certain rules, for example going to the toilet in the middle of class, and, at the other extreme, fighting with them. This was opposite to Sofia's approach of collaboration with students: she had a lot of influence over them, and the students worked well in her class. Simultaneously, she compared her relationship with the students to her relationship with her own adolescent children and used a variety of writing and research activities in the media classroom, based on the use of general purpose programs. All these factors suggested that ICT was used by Sofia for expanding the negotiation and interchange between herself and her students.

On the other hand, the kind of relationship Ricardo had with his students meant his influence over them was reduced. Moreover, one of the main aspects he reported when referring to them was that they were badly behaved, but at the same time, young. In the media classroom he worked with them in the practice of grammar, reading on the screen and copying information from the screen to their notebooks. The kind of programmes he used included drill and practice software and informative papers. All these elements suggest that Ricardo used ICT for controlling his students' behaviour. 
Finding these elements in the data, Activity Theory (AT) presented certain shortcomings. AT enabled the explanation of the school context and the way in which the teachers coordinated, or not, their work inside the activity system, as well as how the activity system in which the SEC ${ }^{21}$ Project Team participated could or could not integrate their work with the school work. At this point there was a need of looking at other theories that could help explain these data. The sociology of emotions was the basis found after a long period of search.

Below is an excerpt of a transcription showing one way in which the data are being analysed.

\section{Observation notes (from the observation + the video)}

Ricardo: ... wait there 'chicos' (youngsters)

Boy1: teacher!

The noise created by the voices of the students is increasing.

Ricardo: ... leave it there (to boy1)... let's see... are you all in material design in computer?... let's see... your attention... I am going to give an extra indication to everyone... if I see someone playing and that means not listening to the indications... the first thing I will do is to ask them to stand up as it would be evident there is no intention of working with the group... and it will be the last time this person comes to the media classroom... because their interest is not evident... where are you moving, Vanessa? (to a girl, Ricardo goes towards her)... did I tell you to do that already?... (whispers, the students have a certain screen in front and should finish listening to the teacher before pushing the enter key. did not you listen to what I indicated?(he goes towards Vanessa and her partner's place)... It is because I (inaudible, but his voice sounds higher in tone, although lower in volume)... I had put you already in that place (pointing out at the screen in which everybody should be working)... I do not know why you do not have it (inaudible)...

Vanessa points at the boy next to her, while starting an inaudible sentence. I feel a bit ashamed.

Ricardo (interrupting): Vanessa, listen to the indication...

Ricardo walks towards the centre of the classroom

There could be many possible ways of interpreting the interaction presented here. However, not leaving aside emotions can be fruitful for understanding 
what is going on in the classroom. In this excerpt, it is possible to see how emotions are running along the way in the interaction between teacher and students. As Csordas (1990) suggests, emotions are played out in the social ground. Apparently, Ricardo did not know what to do in a situation like this and emotions were being played out in his interaction with the students. After some of his classes, we had the opportunity to talk and he expressed how complicated it was for him to deal with students. Interestingly, Ricardo seems to be using anger as one of the resources to negotiate the relationship with Vanessa, in this case, maybe as he lacks any other strategies for relating to the students. Additionally, it is possible that Ricardo's anger is accounting for certain institutional limits in Mexican secondary schools, and in general in the Mexican educational system as, for example, he has more than 200 students, and teaches 7 hours a day.

This brief example presents how emotionality can be analysed in relation to teachers' practices and knowledge, showing how they can be understood as products and resources in interaction and participation within the classroom.

\section{SOME IMPLICATIONS OF THIS WORK}

This section presents some of the theoretical, practical and methodological implications for continuing the development of this study.

So far, this research has discovered some diverse elements to sustain the social character of emotions, by describing how they develop in the social context of the classroom. As Williams and Bendelow affirm, emotions are "embodied, purposive, meaningful responses to situations" (1998a: xviii). What is more, emotions seem to be not only products, but also resources in social interaction in the classroom.

At a theoretical level, taking forward Vygotsky's proposition that "the logic of character development is the same as the logic of any development, all that develops, develops by necessity" (1993: 155), The data presented above suggests that in the context of interactions, emotional expression seems to be responding to the conditions of the context. As a consequence, understanding how emotions are played out in and through their participation in social practices could offer new insights to our understanding of what occurs in the context of practices, and particularly of teaching practices. In this way, there are diverse concepts that could be put on the table, such as distributed emotions, emotional engagement with artefacts, or more broadly, emotional practices, and also in relationship to knowledge, the role of emotions in knowledge, or even, possibly, emotional knowledge. 
In this way, the results of this research can open up important questions about the understanding of teachers' practice and knowledge, as well as more generally to cultural psychology and to neurosciences. For example: What is the place for emotions in the classroom? In what ways cognition impacts emotions? To what extent, teacher's emotions are engaged within their knowledge? Do cultural differences have an impact in the areas of the brain used? Simultaneously, taken as a departure point, the unity of emotionality and cognition in human practices can help to break certain dichotomies, such as rational/irrational, public/private, individual/social, personality/culture.

Understanding emotionality can offer new light on teachers' practices and teachers' knowledge with and without the use of ICT, in particular ways. On the one hand, by giving additional support to the idea that the implementation of changes cannot be reduced to a technical application of a pre-set solution; on the other, by understanding some aspects of the particularities of teaching practices, which may currently seem quite obscure. So far, the findings seem to point to an understanding that teachers' knowledge is also integrated by emotions and feelings, as they seem to be used to understand (or not) and to communicate (or not) about social events and within social practices. Emotions also seem to be psychological tools (Vygotsky, 1987, 1997, 1999) and by understanding them in this way, we can start giving an account of emotionality in individual teacher practices and its role in teacher knowledge. With this aim, it is important to understand how emotions in the wild develop: "one must examine the relationship of intellect and affect, a relationship which forms the focus for all the problems which interest us, and we must examine that relationship not as an object, but as a process." (Vygotsky, 1993: 240).

Finally, this research could also offer a contribution to methodology, as it could give "new relevance to the ethnographer's emotional responses to fieldwork" (Lutz \& White, 1986: 415). This is also a necessary step in understanding diversity, as in the integration of the complex relationships between emotion and cognitions, the cultural differences can be better understood. 


\section{BIBLIOGRAPHIC REFERENCES}

Ashforth, B. E. and R. H., Emotional labor in service roles: The influence Humphrey, 1993 of identity. In: Academy of Management Review, 18: 88-115.

Bakker, A., C. Hoyles, P. Kent. \& R. Noss., 2006

Cole, M., 1996

Cole, M. and J. Derry, 2005

Cochran-Smith, $\mathrm{M}$. and S. L. Lytle, 1999

Csordas, T. J., 1990

Csordas, T. J. (ed.), 1994

Damasio, A.R., 1994

Damasio, A.R., 1999

Day, C., 1993
Improving work processes by making the invisible visible. In: Journal of Education and Work, London, 19 (4): 343-361.

Cultural psychology: A once and future discipline. Cambridge, Mass, Belknap Press of Harvard University Press.

We have met technology and it is us. In: Robert J. Sternberg, David D. Preiss (Eds.). Intelligence and technology: the impact of tools on the nature and development of human abilities. New Jersey, Lawrence Erlbaum Associates.

Relationships of knowledge and practice: Teacher learning in communities. In: Review of Research in Education, 24: 249-305.

Embodiment as a paradigm for anthropology. In: Ethos, 18: 5-47.

Embodiment and experience: The existential ground of culture and self. Cambridge: Cambridge University Press.

Descartes' error: Emotion, reason, and the human brain. New York: Penguin.

The feeling of what happens: Body and emotion in the making of consciousness. New York: Harvest Books.

Reflection: A necessary but not sufficient condition for professional development. In: British Educational Research Journal, 19:83-93. 
Engeström, Y., 1987

Engeström, Y., 1994

Engeström, Y. and

D. Middleton, 1998

Freud, S., 1971

Goodson, I. F., 1992

Hammersley, M. and

P. Atkinson, 1995

Hargreaves, A., 2000

Hargreaves, A., 2002a

Hargreaves, A., 2002b

Hochschild, A. R., 1983

Hochschild, A. R., 1998
Learning by expanding. Helsinki, Orientakonsultit.

Training for change: New approach to instruction and learning in working life. Geneva: International Labour Office.

Cognition and communication at work. Cambridge, Cambridge UP.

Lecture XXIII: The paths to the formation of symptoms. In: S. Freud (ed.), The complete introductory lectures on psychoanalysis. London, Allen and Unwin. pp. 358-377.

Sponsoring the teacher's voice. In: A. Hargreaves and M. Fullan (eds), Understanding teacher development. London, Cassell.

Ethnography: principles in practice. London, Routledge.

Mixed emotions: teachers' perceptions of their interactions with students. In: Teaching and Teacher Education, 16: 811-826.

The emotions of teaching. In: Teachers College Record, 103(6): 1056-1080.

Teaching and betrayal. Teachers and teaching. In: Theory and Practice, 8: 393-407.

The managed heart. Commercialization of human feeling. Berkeley: University of California Press.

The sociology of emotion as a way of seeing. In: G. A. Bendelow and S. J. Williams (eds), Emotions in social life: critical themes and contemporary issues. London, Routledge. pp. 3-16. 
Hochschild, A. R., 2005 Rent a mom and other services: Markets, meanings and emotions. In: International Journal of Work Organisation and Emotion, 1: $74-86$.

Jaggar, A. M, 1989

Love and knowledge: Emotion in feminist epistemology. In: S. R. Bordo and A. M. Jaggar (eds) Gender/Body/Knowledge: Feminist reconstructions of being and knowing. New Brunswick, London: Rutgers University Press.

James, W., 1884

Labaree, D., 2000

Lave, J., 1988

Lave, J. and E. Wenger, 1991

Lave, J. and S. Chaiklin, S., 1993

Lutz, C. and

G. M. White, 1986

Mercado, R., 2002

Morris, J. A. and

D. C Feldman, 1996

Nardi, B. A., 1996
What is an emotion? In: Mind, 9, pp. 185-205.

On the nature of teaching and teacher education: Difficult practices that look easy. In: Journal of Teacher Education, 51(3), pp. 228-233.

Cognition in practice: mind, mathematics and culture in everyday life. Cambridge, Cambridge University Press.

Situated learning: Legitimate peripheral participation. Cambridge, Cambridge UP.

Understanding practice: Perspectives on activity and context. Cambridge, Cambridge University Press.

The anthropology of emotions. In: Annual Review of Anthropology, pp. 405-436.

Los saberes docentes como constru cción social. La enseñanza centrada en los niños. Mexico: Fondo de Cultura Económica.

The Dimensions, antecedents, and consequences of emotional labor. In: The Academy of Management Review, 21: 986-1010.

Contextand consciousness: Activity theory and human-computer interaction. London, MIT Press. 
Nardi, B. A. and V. O'Day, Information ecologies: Using technology with 1999 heart. Cambridge, Mass, MT Press

Piaget, J., 1968

Six psychological studies. London: University of London Press.

Piaget, J., J. Tomlinson \& The child's conception of the world. London:

A. Tomlinson, 1973 Paladin.

Rainbird, H., A. Fuller \& A. Munro, 2004

Roth, W. M., 2007

Salomon, G., 1993

Salomon, G., (ed.), 1994

Scribner, S. and M. Cole, 1981

Spinoza, B., 1959

Suchman, L. A., 1987

Shweder, R, 1990
Workplace learning in context. London: Routledge.

Emotion at work: A contribution to thirdgeneration. In: Mind, Culture, and Activity, 14, pp. 40-63.

Distributed cognitions: Psychological and educational considerations. Cambridge, Cambridge University Press.

Interaction of media, cognition, and learning: an exploration of how symbolic forms cultivate mental skills and affect knowledge acquisition . Hillsdale, N.J. Hove: Enlbaum.

The psychology of literacy. Cambridge, Mass. Harvard University Press.

Ethics: and on the correction of the understanding; and on the way in which it may be directed towards a true knowledge of things. London, Dent.

Plans and situated actions: The problem of human-machine communication. Cambridge, Cambridge University Press

Cultural psychology. What is it? In: J. Stigler, R. Shweder and G. Herdt (editors), Cultural psychology: Essays on comparative human development. Cambridge University Press. pp. 1-43. 
Vygotsky, L.S., 1978

Vygotsky, L. S., 1987

Vygotsky, L. S., 1993

Vygotsky, L. S., 1997

Vygotsky, L. S., 1998

Vygotsky, L. S., 1999

Williams, S. J. and

G. A. Bendelow, 1998a

Williams, S. J. and G. A. Bendelow, 1998b
Mind in society: The development of higher psychological processes. Cambridge, MA:

Harvard University Press. (Published originally in Russian in 1930).

The collected works of L S. Vygotsky. Volume 1: Problems of General Psychology. New York, Plenum Press.

The collected works of L.S.Vygotsky. Volume 2: The fundamentals of defectology. New York, Plenum Press.

The collected works of L.S. Vygotsky. Volume 3: Problems of the theory and history of psychology. New York, Plenum Press.

The collected works of L S. Vygotsky. Vol. 5: Child psychology. New York, Kluwer Academic/Plenum.

The collected works of LS. Vygotsky. Vol. 6, Scientific legacy. New York, Kluwer Academic/ Plenum Publishers.

Introduction: Emotions in social life. Mapping the sociological terrain. In: G. A. Bendelow and S. J. Williams (eds), Emotions in social life: Critical themes and contemporary issues. London, Routledge, pp. xv-xx.

Sociological themes: embodied issues. London, Routledge. 